\title{
Influence of Positivism on Social Science: A Literature Review
}

\author{
Dr. Wenceslaus Mselya Sobayi \\ Faculty of Arts and Social Sciences, University of Nottingham, Malaysia Campus
}

\begin{abstract}
The influence of positivism on social science, is increasing. For more than half a century, there has been a continuous philosophical debate on which philosophical perspective is the right one for social science. This paper examines two contradicting philosophical perspectives of positivism and interpretivism and how they fit into social science. Thus, the research question here is how positivism and interpretivism fit into social science. The paper discusses the influence of positivism on social sciences, and the most cited contributors in literature, that play an important role in the existing philosophical debate. The paper suggests that interpretivism is more suitable for social science.
\end{abstract}

Keywords: Positivism, Interpretivism, Social Science, Philosophical Debate

DOI: $10.7176 /$ RHSS/11-23-02

Publication date: December $31^{\text {st }} 2021$

\section{Introduction}

\subsection{Background}

The English noun positivism was re-imported in the 19th century from the French word positivisme, derived from positif in its philosophical sense of 'imposed on the mind by experience' (Alain et al. 2000). Positivism is part of a more general ancient quarrel between philosophy and poetry, notably laid out by Plato and later reformulated as a quarrel between the sciences and the humanities (Kieran 1997). In contrast to the positivist movement, asserted the superiority of the science of the human mind (the humanities, in other words), on the grounds that natural sciences tell us nothing about the inward aspects of things (Morera 1990).

This study intends to provide philosophical contributions to argumentation structure and consistency, that calls for a need to look at the philosophical debate on which philosophical perspectives namely positivism and interpretivism fits into social science (Blakely 2013). Thus, the research question here is how positivism and interpretivism fit into social science.

Leo Strauss, Charles Taylor and Alasdair MacIntyre both advocated on the use of interpretivist approach in social science (Blakely 2013). These philosophers strongly protested against the use of positivism in social science research (ibid).

Initially, Strauss criticized the use of positivist approach by indicating key weaknesses of positivism in social science (Strauss 1965; 1989; 1997). Later, Taylor and MacIntyre criticized positivistic thought in social science and propose alternatively the use of interpretive approach to social science (Taylor 1980; 1988; 1995; 2007; MacIntyre 1973; 1978; 1986; 2007). Although, their criticism do not mean that they should take the credit for inventing interpretive approach. Leo Strauss, Charles Taylor and Alasdair MacIntyre build their arguments from works of others, such as: linguistic philosophies of Peter Winch and Ludwig Wittgenstein; the phenomenology of Heidegger and Gadamer; and the cultural studies of E.P. Thompson to name only a few (Blakely 2013). Hence, the works of MacIntyre and Taylor it's not original but rather helped to provide us interpretive or hermeneutic philosophy of social science (ibid).

Bernstein (1978) describes that historically, it took over fifty years before this new "interpretive turn" emerged and welcomed in the English-speaking world. Yet today the reforms of this turn have stalled (Blakely 2013). Many social scientists now accept certain interpretive criticisms of their work, but, they also tend to treat interpretivism as one method among many, one more tool in a kit (King et al. 1996; Box-Steffensmeir et al. 2008). Hence, essays of Taylor and MacIntyre seek to reassert the case for interpretive social science (Blakely 2013).

MacIntyre and Taylor adopted interpretive conceptions of the human person against what they saw as the overly mechanistic and reductive tendencies of various intellectual and political strains in the contemporary world (Blakely 2013). MacIntyre and Taylor both insisted that explaining social reality requires engaging with the beliefs, language, and meanings of ordinary people, thus, Interpretive theory is mobilized by these thinkers to resist modernity's tendency to authorize rule by experts, managers, and technocrats (ibid). In promoting, interpretive approaches to explaining human action, Taylor and MacIntyre wanted to give voice to an antitechnocratic and humanistic vision of social science.

\subsection{Study Objective}

To examine two contradicting philosophical perspectives of positivism and interpretivism and how they fit into social science. 


\section{Methodology}

This is a secondary research. Document Analysis was chosen in gathering data, as it involved a detailed examination and review of documents related to the subject under study. The document analysis as a research method was preferred, because data were collected from documents in a more cost-effective manner (Mogalakwe 2006). During analysis, NVivo was employed for developing thematic codes. The following is a table, indicating thematic codes developed by the software:

Sources column represent no. of authors coded, and references no. of citations (i.e. quotes) for a particular theme.

Thematic codes for research question of the study: how positivism and interpretivism fit into social science?

\begin{tabular}{|l|c|c|l|l|}
\hline Description of the theme & Sources & References & Created On & Created By \\
\hline $\begin{array}{l}\text { Positivism versus interpretivism in } \\
\text { social science }\end{array}$ & 6 & 21 & 14 Oct 2021, 11:10:45 & WMS \\
\hline The Rise of Positivism in Philosophy & 11 & 26 & 14 Oct 2021, 11:16:00 & WMS \\
\hline $\begin{array}{l}\text { The Rise of Positivism in the Study of } \\
\text { Social Science }\end{array}$ & 9 & 21 & 14 Oct 2021, 11:11:53 & WMS \\
\hline $\begin{array}{l}\text { The Rise of Positivism as Modern } \\
\text { Power }\end{array}$ & 10 & 17 & 14 Oct 2021, 14:30:48 & WMS \\
\hline
\end{tabular}

Source: NVivo software, 2021

\section{Findings}

\subsection{Positivism versus interpretivism in social science}

Most of twentieth century positivism became predominant not only intellectually but also as a set of techniques and practices, that is, as a form of power (Blakely 2013). How did positivism first emerge? In After Virtue MacIntyre suggests that one place to locate the origin of positivism is in seventeenth and eighteenth century attempts to transfer the mechanistic forms of explanation of Newton's physics into the social sciences (MacIntyre 2007). Taylor similarly argues that this movement began with the belief that human behavior ought to be "understood according to the canons ... [of] the seventeenth-century revolution in natural science." (Taylor 1985)

In this sense positivism was born when Enlightenment intellectuals tried to eradicate the influence of classical and medieval teleology (or explanation according to human purposes as conceptualized by Aristotle) in favor of mechanistic and impersonal forms of causation (Blakely 2013). Instead of explaining human behavior by reference to intentions or purposes, Enlightenment intellectuals increasingly favored mechanistic forms of explanation inspired by the new physics (Turner 2003).

In such origins, Taylor suggests that we can also make out a "metaphysical motivation" that informs all kinds of positivism from the seventeenth century up to the present day (Taylor 1985). Inspired in part by the sheer prestige and success of the natural sciences, researchers in the human sciences have increasingly attempted to reduce or eliminate specifically human or anthropocentric properties from the explanation of the world in favor of hard facts similar to those of the natural sciences (Blakely 2013).

Blakely (2013) describes that a regular feature of positivism, in other words, is the assumption that the specifically human (which is thought of as subjective) can be reduced or at least explained in terms of the specifically nonhuman (which is thought of as objective and factual). One particularly important example of this is the effort, dating back to the Enlightenment, to dichotomize facts and values (ibid).

As mentioned, MacIntyre and Taylor as interpretivists, are critical of this particular positivist doctrine (Blakely 2013). Since, there had been an attempt by positivists to explain human behavior in terms of ostensibly brute facts about individuals or groups (for example, their income level, race, political party, or gender) instead of engaging with their beliefs and meanings, and thus frequently serve a subordinate function if they are not entirely subtracted from positivist explanations $(i b i d)$.

Of course, now that we have some general parameters with which to identify positivism as an intellectual tradition, it is apparent that such parameters are too abstract to do much philosophical work (Blakely 2013). As MacIntyre puts it, there have been "many positivisms and not just one or even two" such that the "virtues of positivism emerge only in the detail of particular versions, not in summaries of its most general philosophical theses." (MacIntyre 1986).

For many centuries, positivism has been capturing the intellectual mainstream (Blakely 2013). Theories and practices have been developed, to support analytic philosophy, modern political science, and modern management and governance (Gunnell 1975). Positivism has crowned the natural sciences, and it is considered as the supreme model, in the meantime attempted to subtract or at least demote the specifically human dimensions of reality (Blakely 2013). Positivism, in this regard, is not simply an intellectual movement, but a cultural movement, and ultimately a form of power (ibid).

Comteans do consider positivism as the supreme model, and argue that positivism advocates the use of 
scientific methods to uncover the laws according to which both physical and human events occur, thus, positivism is a way of understanding based on science, however, interpretivists argue that positivism ignore the role of the 'observer' in the constitution of social reality and thereby fail to consider the historical and social conditions affecting the representation of social ideas (Fagan, 2003). Positivism falsely represents the object of study by reifying social reality as existing objectively and independently of the labour that actually produced those conditions (ibid).

Further, Fagan (2003) argues, representation of social reality produced by positivism is inherently and artificially conservative, helping to support the status quo, rather than challenging it. This character may also explain the popularity of positivism in certain political circles $($ ibid $)$.

\subsection{The Rise of Positivism in Philosophy}

The rise of positivistic philosophies happened in the twentieth century and became dominant in Anglophone philosophy due to advent and development of analytic philosophy (Blakely 2013). Analytic philosophy has roots extending into the work of European thinkers such as Gottlob Frege and the young Wittgenstein but its emergence in the Anglophone world was largely the result of G. E. Moore's and Bertrand Russell's early attempts to revive the tradition of British empiricism (ibid).

Empiricism needed reviving because at the turn of the century idealism reigned supreme in England (Blakely 2013). British idealists led by F. H. Bradley and T. H. Green had under the influence of Hegel championed ahistorical, holistic and metaphysical approach to philosophy in which the world was understood in terms of an increasingly complete system of beliefs (ibid).

Although both Russell and Moore had been educated within the tradition of British Idealism, they sought early on to overturn the late nineteenth century dominance of idealism and instead restore the empiricism of Locke, Hume, and Mill (Hylton 1990). They both did so, moreover, by attempting to rehabilitate updated versions of ahistorical and atomistic conceptions of reality discoverable through formal schemes of analysis (ibid).

However, the more important aspect of Moore's essay is the suggestion that as an alternative to idealism, philosophy be reconceived as the activity of decomposing complexes of concepts into their atomistic parts through analysis (Moore 1993). These atoms, Moore believed, were non-temporal, non-mental objects that constituted the elementary stuff of reality and whose apprehension was immediate and unproblematic (ibid).

A related move towards atomistic foundations to knowledge was presented in Russell's early theory of logical atomism (Russell 2009). Russell's logical atomism also clearly borrowed from a view of the world popularized by modern physics (Blakely 2013). Russell distinguished philosophical analysis which arrived at "logical atoms" from the "physical analysis" of science which arrived at "physical atoms," nevertheless Russell did so as part of a wider effort to grant science an authoritative place within the domain of human knowledge with philosophy largely relegated to the role of logically analyzing general problems that science had not yet managed to resolve definitively (ibid).

As with Moore, Russell's philosophy was also meant to overturn the Hegelian conception of knowledge as requiring the understanding of ever wider wholes or systems of historically formed beliefs (Russell 2009). Both Russell's and Moore's turn toward atomistic foundations thus marked a rejection of idealist notions of philosophical understanding as intertwined in historical knowledge (ibid).

Instead, Moore and Russell made appeals to a kind of ahistorical common sense as the starting point for philosophical analysis (Russell 2009). Both Moore's and Russell's forms of atomism, although openly metaphysical, were also meant to rehabilitate empiricism by repudiating its dependence on holistic, historical narratives ( ibid)

Within the formation of early analytic philosophy, this shift was also evident in a small but noisy band of intellectual radicals, the logical positivists, who drew inspiration from the Vienna Circle (Wittgenstein 1922). Unlike Moore and Russell, the logical positivists largely rejected attempts by philosophers to articulate a basic ontology as inherently metaphysical (Ayer 1946). However, like Russell and Moore, the logical positivists accepted both the critique of idealism and the view of philosophy as a form of analysis subordinate to the natural sciences $($ ibid $)$.

Furthermore, analytic philosophers also succeeded in raising the prestige of positivistic views beyond the bounds of philosophy departments into various fields in the human sciences (Smith 1997). For example, psychological behaviorists like Edward Tolman, Clark Hull and B. F. Skinner drew from analytic philosophy's intellectual authority in order to legitimate their approaches (ibid). Likewise, behavioral political scientists made use of a philosophy of science inspired by the analytic tradition (Gunnell 1975). More generally, the overwhelming success and prestige of the natural sciences continued to drive many philosophers and social scientists alike to remake their disciplines in the image of the natural sciences (ibid).

Analytic philosophy was, in this sense, only one part of the larger movement to crown the natural sciences as the supreme model of human inquiry (Gunnell 1975). Ashley and Orenstein (2005) propose that research 
should concentrate on human cultural norms, values, symbols, and social processes viewed from a subjective perspective. Max Weber argued that sociology may be loosely described as a 'science' as it is able to identify causal relationships, especially among ideal types, or hypothetical simplifications of complex social phenomena (ibid).

Thus, Interpretivists usually seeks relationships that are not as "ahistorical, invariant, or generalizable" as those pursued by natural scientists (Ashley and Orenstein 2005). Weber regarded sociology as the study of social action, using critical analysis and verstehen techniques (ibid). Hence, positivism may be supported by "technocrats" who believe in the inevitability of social progress through science and technology (Schunk 2012; Outhwaite 1988).

\subsection{The Rise of Positivism in the Study of Social Science}

Some thinkers criticized the emergence of positivism in all the human sciences including psychology, economics, sociology and particularly political science (MacIntyre 1978). Just like what analytic philosophers did, these critics who studied politics at the turn of the century also wished to transform their discipline into a more empirical, formal, and scientific enterprise (Blakely 2013).

In psychology, the positivist movement was influential, as in 1927 philosophy of science book The Logic of Modern Physics in particular, which was originally intended for physicists, coined the term operational definition, and went on to dominate psychological method for the whole century (Koch 1992). In economics, practising researchers tend to emulate the methodological assumptions of classical positivism, but only in a de facto fashion: the majority of economists do not explicitly concern themselves with matters of epistemology (Boland 2012). Economic thinker Fredrich Hayek rejected positivism in the social sciences as hopelessly limited in comparison to evolved and divided knowledge (Hayek 2013). Hayek argued against positivism by stating that, much (positivist) legislation falls short in contrast to pre-literate or incompletely defined common or evolved law (ibid).

Hayek (2013) further argued that in jurisprudence, "legal positivism" essentially refers to the rejection of natural law; thus, its common meaning with philosophical positivism is somewhat attenuated and in recent generations generally emphasizes the authority of human political structures as opposed to a "scientific" view of law. In the early 1970s, urbanists of the positivist-quantitative school started to question the positivist approach itself, saying that the arsenal of scientific theories and methods developed so far in their camp were "incapable of saying anything of depth and profundity" on the real problems of contemporary cities (Portugali et al. 2012).

Also like early analytic philosophers, in order to do so such students of politics needed to unseat a dominant paradigm which was primarily narrative and historical in approach (Blakely 2013). This older approach to the study of politics and society not only considered historical narratives a form of science but also largely assumed that progress was built into the order of things (Adcock 2003; Bevir 2006). Thus, the study of politics in the nineteenth century tended to take on the form of large-scale historical narratives that made claims to a science of development toward some final goal or end state (Blakely 2013).

Regardless of its causes, what is clear is that the transition away from grand progressive narratives towards atomistic forms of empiricism was the crucial event in the formation of modern political science as a discipline separate from that of history (Adcock 2003). Scholars of politics in the late nineteenth century had for the most part not distinguished between the study of politics and history (Blakely 2013). To the contrary, they largely assumed that the study of one was in some sense the study of the other (ibid). But with the advent of a more empiricist political science, professional historians began to distinguish themselves more and more in terms of the study of the past "for its own sake," while political scientists insisted on the need to discover policy relevant advice by abstracting from historical contexts and articulating the essential features of political and social life (Adcock 2003).

The ongoing debate between these two forms of positivistic political science, one more inductively minded and the other inclined towards deductive generalizations, has largely defined two possible methodological poles within the discipline up to the present day (Bevir 2006). But for our purposes, what is important to emphasize is that these particular forms of empiricist and behavioralist political science were the dominant ones when Taylor and MacIntyre first wrote, as well as when Strauss first turned his attention to critiques of political science (Blakely 2013). This dominance, as we have seen, runs parallel to the empiricism and vaunting of natural science that had reached a zenith in analytic philosophy (ibid).

Likewise, a more extensive survey of the academic landscape would reveal a similar spread of positivism in other disciplines like psychology and economics (Turner 2003). However, we now turn our attention to how the rise of positivism was not merely an academic story but also embodied a major form of modern power (Blakely 2013).

\subsection{The Rise of Positivism as Modern Power}

Positivism asserts that all authentic knowledge allows verification and it assumes that the only valid knowledge 
is scientific (Larrain 1979). Other anti-positivists such as Wilhelm Dilthey, in contrast, fought strenuously against the assumption that only explanations derived from science are valid (Wallace and Gach 2008). Dilthey reprised the argument, that scientific explanations do not reach the inner nature of phenomena, and it is humanistic knowledge that gives us insight into thoughts, feelings and desires (Makkreel 2008). At the turn of the 20th century the first wave of German sociologists, including Max Weber and Georg Simmel, rejected positivism, thus founding the anti-positivist tradition in sociology (Little 2014). The anti-positivists and critical theorists have associated positivism with scientism (i.e. the view that science is the best or only objective means by which society should determine normative and epistemological values), science as ideology (Habermas 1968). Later in his career, German theoretical physicist Werner Heisenberg, Nobel laureate for pioneering work in quantum mechanics, distanced himself from positivism.

In historiography, the debate on positivism has been characterized by the quarrel between positivism and historicism (Wallace and Gach 2008). Historicism is also sometimes termed as historism in the German tradition (Boudon and Bourricaud 1989). Arguments against positivist approaches in historiography include that history differs from sciences like physics and ethology in subject matter and method (Wallace and Gach 2008). That much of what history studies is non-quantifiable, and therefore to quantify is to lose in precision, thus, experimental methods and mathematical models do not generally apply to history, and it is not possible to formulate general (quasi-absolute) laws in history ( ibid).

Positivism has been criticized for its reductionism, i.e., for contending that all "processes are reducible to physiological, physical or chemical events," or "social processes are reducible to relationships between and actions of individuals," and that "biological organisms are reducible to physical systems."(Bullock and Trombley 2000). Thus, Interpretivists have been criticizing the classic formulation of positivism on two grounds: First, it falsely represented human social action (Fagan 2003). Second, Positivists systematically failed to appreciate the extent to which the so-called social facts, that themselves a product of socially and historically mediated human consciousness (ibid).

The measuring of outputs, benchmarks, examinations, and other auditing functions has become an increasingly common way of presenting purportedly objective evaluations of administrators and politicians at the end of the twentieth century (Blakely 2013). Such quantification has been viewed by some historians as a political strategy for coping with the increasing deferment of power to the bureaucracy and experts in democratic societies (Porter 1995). What is certain is that it marks a shift away from the political ethos of the late nineteenth century (Blakely 2013).

The drive for positivistic knowledge has thus been among the best funded intellectual programs in the human sciences of the last century (Blakely 2013). And although a definitive and authoritative social science has eluded researchers, as there has been an undeniable spread of its cultural and political forms (ibid). Indeed, there is a spread of the political authority of positivism (Ross 2003).

\section{Discussion}

Strauss, MacIntyre, and Taylor viewed "positivism" as something larger than just an intellectual movement in philosophy as well as social science. They saw positivism as a cultural-political form, and also a kind of power. These three thinkers, each one of them, formed a particular view, and was primarily based on the shortcomings of positivism.

Strauss, MacIntyre and Taylor, all unanimous refuse to accept positivistic doctrines in the social sciences. Furthermore, MacIntyre and Taylor have contributed to the support of a hermeneutic or interpretive approach. MacIntyre and Taylor have narrated the ways in which an interpretive approach can assist in answering the research question of how positivism and interpretivism fit into social science?

More specifically, this secondary research has revealed that interpretive tradition can assist in addressing problems of positivistic or pseudo-scientific forms of knowledge, practice, power, and social organization in contemporary world. The contributions of MacIntyre and Taylor are relevant and significant, particularly in the philosophy of social science, although the contributions were made during the late twentieth century, however, problems of pseudo-scientific power and authority continue to affect social science.

Therefore, Interpretive social science, reveals importance of ordinary human agency. Thus, it rejects scientific reductivism and impersonal, mechanistic explanations of human life. Further, an interpretive approach opposes the hierarchical arrangements of expert and elite authority. In other words, the use of positivism in social science is mostly preferred by technocrats, bureaucrats, and other managerial members, while interpretivism focusses more to the need of the ordinary and regular citizens. Hence, understanding of ordinary agents and their everyday experiences, is better than the result of a formal, ahistorical, de-contextualized language of science.

\section{Conclusion}

This paper examines two contradicting philosophical perspectives of positivism and interpretivism and how they 
fit into social science. Thus, the research question here is how positivism and interpretivism fit into social science?

MacIntyre and Taylor stand at the centre of this research question of how positivism and interpretivism fit into social science? This is because an interpretive, humanistic approach to social science is critical. However, the full potential of interpretivism in social science is yet to be realized in practice. There is much work left to be done.

The Echoes of positivists and interpretivists debate continue, although sometimes this debate is hard to define and understand. Some scholars/authors do write in different epistemological perspectives and do not properly phrase their disagreements (Hanson 2008). To complicate the issues further, only few scholars/authors explicitly state their epistemological commitments, and their epistemological position, thus one has to guess from either choice of methodology or theory.

\section{References}

Adcock, R. (2003) The Emergence of Political Science as a Discipline: History and the Study of Politics in America, 1875-1910, History of Political Thought Vol. 24 (3), Imprint Academic Ltd., pp. 481- 508

Alain, R., Paul, R. and Josette R. (2000), Le Petit Robert: Dictionnaires Le Robert, (English ed), Volume 8

Ashley D., and Orenstein D. M (2005), Sociological theory: Classical Statements $\left(6^{\text {th }}\right.$ ed), Boston, MA: Pearson Education, pp. 239-240

Ayer, A. J. (1946) Language, Truth and Logic, New York: Dover Publications

Bernstein, R. (1978) The Restructuring of Social and Political Theory, Philadelphia: University of Pennsylvania Press, pp.109-113

Bevir, M. (2006) Political Studies as Narrative and Science, 1880-2000, Political Studies Association

Boland, L.A. (2012) Economic Positivism, Simon Fraser University Burnaby, B.C. Canada available from http://www.sfu.ca/ boland/boland@sfu.ca

Boudon R. and Bourricaud F. (1989), A Critical Dictionary of Sociology, Routledge

Box-Steffensmeier, J., Brady, H., and Collier, D. (2008) "Political Science Methodology," in The Oxford Handbook of Political Methodology, Oxford: Oxford University Press, pp. 29-30

Blakely, J.W (2013) Three Political Philosophers Debate Social Science: Leo Strauss, Alasdair MacIntyre, and Charles Taylor, University of California, Berkeley

Bullock, A. and Trombley, S. (2000), The New Fontana Dictionary of Modern Thoughts, (3 ${ }^{\text {rd }}$ ed) London: Harper - Collins Publishers

Fagan, A. (2003) Theodor Adorno (1903 - 1969) - Internet Encyclopedia of Philosophy, University of Essex, United Kingdom

Gunnell, J. (1975) Philosophy, Science and Political Inquiry, Morristown, NJ: General Learning Press, pp. 60 67

Habermas, J. (1968). Technik und Wissenschalf als Ideologie, Frankfurt: Suhrkamp Verlag, pp. 169, - Towards a Rational Society: Student Protest, Science and Politics, trans. J.J. Shapiro, Boston: Beacon Press, 1970, pp. ix, 132

Hayek, F. A. (2013), Law, Legislation and Liberty: A new statement of the liberal principles of justice and political economy, ( $1^{\text {st }}$ ed), Routledge Classics eBooks, ISBN 9780415522298

Hylton, P. (1990), Russell, Idealism and the Emergence of Analytic Philosophy, Oxford University Press

Kieran, E. (1997), The Educated Mind, University of Chicago Press, pp. 115-116, ISBN 978-0-226-19036-5

King, G., Keohane, R., and Verba, S. (1996) Designing Social Inquiry, Princeton University Press, pp. 38-39

Koch, S. (1992) Psychology's Bridgman vs. Bridgman's Bridgman: An Essay in Reconstruction, in Theory and Psychology, SAGE Publications

Larrain, Jorge (1979) The Concept of Ideology, London: Hutchinson

Little, W. (2014), Introduction to Sociology, (1 ${ }^{\text {st }}$ Canadian Edition), BCcampus Open Publishing

MacIntyre, A. (1973), Ideology, Social Science and Revolution, Comparative Politics 5, Vol. 3: pp. 321- 342

MacIntyre, (1978), Is a Science of Comparative Politics Possible? in Against the Self-Images of the Age, Notre Dame, IN: University of Notre Dame Press

MacIntyre, A. (1986) Positivism, Sociology and Practical Reasoning: Notes on Durkheim's Suicide, in Human Nature and Natural Knowledge, eds. Alan Donagan, Anthony Perovich and Michael Wedin, Boston: D. Reidel Publishing

MacIntyre, A. (2007) After Virtue, Notre Dame, IN: University of Notre Dame Press, pp. 81-85.

Makkreel, R. (2008) Wilhelm Dilthey, The Stanford Encyclopedia of Philosophy, available from URL https://plato.stanford.edu/archives/spr2021/entries/dilthey

Mogalakwe, M (2006) The Use of Documentary Research Methods in Social Research, African Sociological Review, Vol. 10 (1): pp. $221-230$

Moore, G.E (1993), The Nature of Judgment, in: G. E. Moore: Selected Writings, ed. T. Baldwin, New York: 
Routledge

Morera, E. (1990), Gramsci's Historicism: A Realist Interpretation, Routledge, ISBN 0415035406, 9780415035408

Outhwaite, W. (1988) Habermas: Key Contemporary Thinkers, Polity Press (2 ${ }^{\text {nd }}$ ed), ISBN 978-0-7456-4328-1, p. 68

Porter, T. (1995) Trust in Numbers: The Pursuit of Objectivity in Science and Public Life Princeton: Princeton University Press

Portugali, J., Meyer, H., Stolk, E. and Tan, E. (2012) Complexity Theories of Cities Have Come of Age: An Overview with Implications to Urban Planning and Design, Springer Science and Business Media, p.51

Ross, D. (2003) Changing Contours of the Social Science Disciplines, Cambridge History of Science: The Modern Social Sciences, pp. 219-220

Russell, B. (2009), Philosophy of Logical Atomism, Routledge, ISBN 0415474612, 9780415474

Schunk, D. H. (2012), Learning Theories: An Educational Perspective, $6^{\text {th }}$, Pearson Education, Inc., publishing as Allyn \& Bacon, 501 Boylston Street, Boston, MA, 02116, p. 315

Smith, R. (1997) The Norton History of the Human Sciences, New York: W. W. Norton and Company

Strauss, L. (1997), A Giving of Accounts, Jewish Philosophy and the Crisis of Modernity, ed. Kenneth Hart Green, State University of New York Press

Strauss, L. (1965) Natural Right and History, University of Chicago

Strauss, L. (1989) Social Science and Humanism, The Rebirth of Classical Political Rationalism, University of Chicago Press

Taylor, C. (1980) The Philosophy of the Social Sciences, Political Theory and Political Education, ed. Melvin Richter, Princeton University Press

Taylor, C. (1985) Introduction in Human Agency and Language: Philosophical Papers Vol 1, Cambridge University Press

Taylor, C. (1988) The hermeneutics of conflict, Princeton University Press

Taylor, C. (1995) Comparison, History, Truth," in Philosophical Arguments, Harvard University Press, pp. 148151

Taylor, C. (2007) A Secular Age, Cambridge, MA: Belknap Press

Turner, S. (2003) Cause, Teleology and Method in The Cambridge History of Science: The Modern Social Sciences, vol. 7, eds. Theodore Porter and Dorothy Ross, Cambridge, UK: Cambridge University Press, pp. $57-70$

Wallace, E. R. and Gach, J. (2008). History of Psychiatry and Medical Psychology: With an Epilogue on Psychiatry and the Mind-Body Relation, SpringerNature, Switzerland, p. 14

Wittgenstein, L. (1922) Tractatus Logico-Philosophicus, trans. C. Ogden, intro B. Russell, Kegan Paul, London 